SECTION 21. Pedagogy. Psychology. Innovations in the field of education.

\author{
Nikulina Natalya Urienvna \\ $4^{\text {th }}$-year student, \\ Belgorod National Research University, \\ Russia \\ Gudakova Ekaterina Vyacheslavovna \\ $4^{\text {th }}$-year student, \\ Belgorod National Research University, \\ Russia
}

\title{
THE TECHNOLOGY OF JAZZ CHANTS AT THE ENGLISH LESSONS
}

Abstract: This article considers the key components of "Jazz chants" and to study the main opportunities and advantages of their using at the English lessons on the basis of the secondary education.

Key words: Jazz chants, English language, Pedagogy, language teaching methods, phonetic skills, intonation, rhythm.

\section{ТЕХНОЛОГИЯ ДЖАЗОВЫХ ЧАНТОВ НА УРОКАХ АНГЛИЙСКОГО ЯЗЫКА}

Аннотация: Данная статья призвана раскрыть и рассмотреть главные компоненты понятия «джазовый чант», изучить возможности и выявить преимущества использования чантов на уроках английского языка на базе среднего общеобразовательного учреждения.

Ключевые слова: Jazz chants, джсазовый чант, английский язык, педагогика, методика, фонетический навык, интонация, ритм.

Нынешнее время предлагает множество методик и технологий личностноориентированного обучения. Непрерывное совершенствование произносительных навыков, фонетическая правильность речи - одно из главных условий пользования иностранным языком как средством коммуникации. Полноценная речь на иностранном языке немыслима без отработанного до автоматизма произношения, которое позволяет говорящему не задумываться во время акта коммуникации о том, как артикулировать отдельный звук. Одной из них является технология «Jazz Chants». Мы полагаем, что использование джазовых чантов в процессе овладения английским языком является эффективным средством формирования коммуникативной компетенции.

На современном этапе далеко не каждый УМК отводит должное внимание формированию фонетического навыка у учащихся. Необходимо обладать немалым опытом, чтобы уметь запланировать урок, принимая во внимание все аспекты обучения и не упустить ничего важного. И зачастую фонетику отодвигают на второй план. Однако неправильно поставленное произношение ведет к целому ряду проблем:

1) учащиеся с трудом понимают друг друга;

2) неправильное произношение часто приводит к неграмотному письму;

3) ученик, неправильно произнесший слово или фразу, боится быть осмеянным одноклассниками, теряет уверенность в своих ответах; у него снижается мотивация к работе на уроке и, как следствие, теряется интерес к английскому языку.

С каждым годом обучения содержание речи усложняется, и основной акцент обучения делается на совершенствование грамматических и лексических умений, а 
произношение упускается из виду. Становится более заметным влияние родного языка [2, с. 203]. Ввиду физиологических и психических особенностей подростки часто испытывают трудности в сосредоточенности на уроке; бурная активность и импульсивность школьника приводят к неустойчивости внимания, его частой отвлекаемости. Активная познавательная деятельность, интересные виды занятий - вот что делает урок интересным для школьников, способствует организации их внимания и восприятия [1, с. 130].

Основная психологическая потребность школьников - общение, поэтому появляется необходимость использования таких приемов и форм работы, которые бы удовлетворяли потребность школьников в общении и помогали усваивать правила и нормы вербального и невербального поведения [3, с. 32].

Современный учитель английского языка располагает богатым выбором УМК, дополнительной литературой по предмету, книгами по чтению, аудиоматериалами и Интернет ресурсами. И одним из действенных приемов работы на уроке является использование джазовых чантов. Он насыщен языковыми реалиями повседневной жизни, чего нельзя сказать о многих стихах, где важна чаще рифма и нарушается натуральность фразы.

Что же представляет из себя джазовый чант с точки зрения методики обучения? Прежде всего, необходимо выявить основные характеристики джазовой музыки в целом. Джаз (англ. jazz) как род профессионального музыкального искусства сложился на рубеже XIX и XX вв. в результате синтеза элементов двух музыкальных культур европейской и африканской. Среди его основных черт можно выделить полиритмичность, многократную повторяемость основного мотива, исполнение по схеме «зов и ответ», вокальную экспрессивность, импровизацию.

Теперь следует дать определение слову «чант». Согласно словарю издательства Longman «chant - words or phrases that are repeated again and again by a group of people», т.е. «чант» представляет собой многократно повторяемый речевой элемент [5, с. 125].

Таким образом, джазовый чант - это ритмическое и динамичное выражение коротких разговорных рифмовок, связанных с определенными ситуациями, которые исполняются на фоне джазовой импровизации.

Если задуматься, вся наша жизнь пронизана ритмами - ритм дыхания, биение сердца, пульс, суточный ритм, годовой ритм. Поэтому мир музыки и ритма близок нашей природе, динамичному образу жизни.

Учащиеся, как правило, хорошо осведомлены о мире современной музыки, и если учитель учтёт их музыкальные предпочтения, то это может способствовать развитию стойкой мотивации к изучению иностранного языка.

Все джазовые рифмовки способствуют развитию навыков разговорной речи, а именно помогают учащимся быстро и легко запомнить фразы повседневного обихода. По сути это зубрёжка, только весёлая и увлекательная. Рифмовки остроумны, задорны, сочинены с чувством юмора и любовью к языку. Поэтому работать с ними просто и чрезвычайно приятно. А великолепное музыкальное оформление создаёт творческую атмосферу в классе, располагает ребят к общению, расслабляет, поднимает настроение. Джазовые чанты очень разнообразны, работа с ними добавляет в привычный школьнику ход урока элементы праздника, задора и веселья. Кроме того, содержание каждого джазового чанта сосредоточено на различной лексике и грамматике, что также помогает при повторении лексических единиц и грамматических структур. Рассмотрим для примера джазовый чант по теме «My Personal computer»:

Cursor, keyboard, Monitor, mouse.

There's a personal computer in my house.

Diskette, disk drive. Where's the CD? 
My personal computer Is looking for me.

Cursor, keyboard, Monitor, mouse.

I like that PC In my house,

It's user-friendly, If you try.

But don't forget to switch on the power supply [4, c. 58].

Как можно заметить, он небольшой и потому легок для запоминания. Отметим ключевые моменты при работе с данным чантом:

- расширяется запас слов по теме «Му РС»;

- отрабатывается речевой оборот there is/are;

- отрабатываются сокращенные формы, характерные для разговорной речи: There is (There's), Where is (Where's) and It is (It's);

- формируется употребление определенного/неопределенного артикля (the $\mathrm{CD}$, the power supply в сравнении с употреблением неопределённого артикля a personal computer;

- предлагаемый Jazz Chant основан на употреблении Present Simple Tense;

- отрабатываются устойчивые выражения со словом time (all the time, in the morning, in the evening)

Как видим, один и тот же джазовый чант может использоваться на уроке для отработки фонетики, лексики и грамматики, но самое главное - они позволяют ученику использовать их в разных речевых ситуациях без страха сделать ошибку в речи. Следует также отметить, что все они небольшие по объему, и что немаловажно, полны доброго юмора.

Для успешной работы с джазовыми чантами необходимо соблюдение ряда простых, но важных условий, которые позволят привлечь внимание учеников. Вопервых, детям нужна радость узнавания, но это узнавание накладывается на старый выверенный ритм. Одной из особенностей детей младшего школьного возраста является желание рассказывать и слушать одни и те же сказки, стихи и песенки. Они с удовольствием делают это несколько раз подряд. Поэтому мелодии должны быть простыми, динамичными, запоминающимися, или же преподавателю следует выбирать хорошо известные детям композиции. Во-вторых, речь и музыка в чанте находятся в гармонии с движением исполнителя. Это захватывает всех окружающих, призывая действовать вместе. Поэтому полезно иметь на уроке музыкальные инструменты и другие приспособления, отбивающие ритм (ложки, бубны, кастаньеты, барабанные палочки, трещотки, погремушки). Не менее увлекательным будет выполнение какихлибо движений в такт музыке или же ученики могут просто хлопать в ладоши, топать ногами, ходить по классу. В-третьих, необходимо помнить, что джазовые чанты - это веселое и позитивное занятие, поэтому школьники должны чувствовать себя несколько свободнее, чем они привыкли на уроках и не стесняться подпевать. Учитель, способный стать речевым партнером детей, может успешно использовать этот инновационный и привлекательный прием для обучения языку. Ни детям, ни учителю не требуется особой музыкальной подготовки и особых вокальных данных. Важно лишь чувство ритма и желание.

Для некоторых учителей идея использования чантов в обучении иностранному языку может показаться неприемлемой вследствие возникновения в классе излишнего шума и движений. Если учебный процесс организован правильно, учитель дает четкие и понятные инструкции, владеет ситуацией и отношения учителя с детьми отличаются доброжелательностью и пониманием, этого не следует опасаться.

Несмотря на то, что джазовые чанты увлекательны и полны юмора, к работе с ними следует подойти со всей серьезностью, потому мы определили несколько этапов:

1) Объяснение ситуации, которую представляет чант. 
2) Первое музыкальное предъявление чанта.

3) Чтение печатного текста, отработка сложных грамматических конструкций, работа с интонацией и объяснение особенностей произношения.

4) Перевод текста джазового чанта.

5) Фонетическая отработка чанта с использованием ритма.

6) Повторное прослушивание с опорой на текст.

7) Разделение класса на две или три группы для разыгрывания диалога чанта.

На последующих уроках достаточно несколько раз повторить чант, чтобы слова запомнились прочно и надолго.

Работу с джазовыми чантами можно проводить на любом этапе урока в зависимости от методической задачи: в качестве фонетической зарядки - в начале урока; в середине или в конце урока - для тренировки и закрепления лексического и грамматического материалы по теме урока; или же пятиминутная разрядка, восстанавливающая работоспособность учащихся.

Итак, каковы же преимущества применения данной технологии? Во-первых, работа с чантами положительно эмоционально окрашена, что содействует успешному усвоению материала и созданию благоприятной обстановки в классе. Во-вторых, чанты - это прекрасный материал для отработки ритма, интонации иноязычной речи, совершенствования произношения и, как следствие, развития музыкального слуха. Помимо этого джазовые чанты помогают совершенствовать постановку правильного логического ударения, отработку мелодии и интонации, в условиях современной школы считающейся невыполнимой задачей. В-третьих, работа с джазовыми чантами позволяет активизировать грамматические конструкции и отрабатывать разговорные клише. Они способствуют развитию как монологической, так и диалогической речи. Джазовые чанты не отнимают много времени на уроке, так как органично вписаны в процесс обучения в целом.

Таким образом, активное использование джазовых рифмовок на уроках иностранного языка направлено не только на фонетический аспекта языка, но и способствует формированию коммуникативной компетенции в целом, повышает мотивацию изучения иностранного языка и снимает психологические барьеры, возникающие у школьников в процессе изучения английского языка.

\section{Литература}

1. Гальскова Н.Д. Современная методика обучения иностранным языкам: пособие для учителя. - 2-е изд., переаб. и доп. - М.:Аркти, 2003. - 192с.

2. Хуторской А.В. Методика личностно-ориентированного обучения. Как обучать всех по-разному?: пособие для учителя. - М.: Изд-во ВЛАДО-ПРЕСС, 2005 -383 с.

3. Якиманская И.С. Технология личностно-ориентированного обучения. М.: Сентябрь, $2000-176 \mathrm{c}$.

4. Carolyn Graham. Jazz Chants; Small Talks. - OUP 1979, 1987. - 132 c.

5. Longman Dictionary of Contemporary English, 4th ed. - Harlow: Pearson Education Limited, $2003-567 c$. 